\title{
High use of antibiotics in elderly patients at discharge after hospitalization for acute abdominal pain
}

\author{
Jakob S Jensen ${ }^{*}$, Helle L Ipsen, Hanne Jørsboe \\ From 6th Danish Emergency Medicine Conference \\ Odense, Denmark. 20-21 November 2014
}

\section{Background}

$8 \%$ of the annual discharges at our hospital of NykøbingFalster (NFS) are registered as acute abdominal pain. A former study in our department based on national data has demonstrated a high use of pain-killers, antibiotics, and antacids in these patients. We want to investigate if there is a difference in the drug consumption before and after hospitalization due to unspecific abdominal pain, in patients aged 18-60 compared to patients aged $80+$.

\section{Methods}

A retrospective audit study was performed in a group of younger patients (20-60 years) and a group of elderly (80+ years) with unresolved abdominal pain before and after admittance to NFS in 2012. Patients were included with a discharge code of acute abdominal pain without any explanation (ICD-10 code R10). We assessed the use of medication on the admission day and new drugs prescribed at discharge supplemented with duration of hospitalization, frequency of re-admittance within 30 days, 30 days mortality rate, and correct disease-coding. The following groups of drugs were studied; antibiotics, painkillers, and antacids including $\mathrm{H} 2$-antagonists. In 16 of 74 cases in the elderly and 3 of 74 cases in the young, we found a specific diagnosis and their data was excluded.

\section{Results}

The study included 71 patients (20-60 years), mean age 37 years, and 58 patients (80-99 years) mean age 85 years. The $80+$ year patients versus the younger had a longer length of stay, at 4.67 days (1-65) versus 2 days (1-12), readmission rate was higher at $28 \%$ versus $10.8 \%$ and mortality rate was $19 \%$ versus $0 \%$. In general, the elderly were prescribed more medication at arrival and increased at

\footnotetext{
* Correspondence: jsoj@regionsjaelland.dk

Emergency Department, Nykøbing-Falster Hospital, Nykøbing-Falster, Denmark
}

discharge compared to the younger. The elderly had a significantly increase in new antibiotics from $7 \%$ at admission to $28 \%$ at discharge.

\section{Conclusion}

We found that the elderly patients had a very high mortality rate. They were discharged without explanation for their abdominal pain, but had prescribed more new symptomatic medication as painkillers and antacids compared to the younger. As a new finding, we showed that the elderly in $28 \%$ of the cases were treated with antibiotics at discharge. Whether this is a bias to wrong disease coding or to symptomatic use of antibiotics with weak indications need further investigation.

Published: 16 July 2015

doi:10.1186/1757-7241-23-S1-A25

Cite this article as: Jensen et al:: High use of antibiotics in elderly patients at discharge after hospitalization for acute abdominal pain. Scandinavian Journal of Trauma, Resuscitation and Emergency Medicine 2015 23(Suppl 1):A25.

Submit your next manuscript to BioMed Central and take full advantage of:

- Convenient online submission

- Thorough peer review

- No space constraints or color figure charges

- Immediate publication on acceptance

- Inclusion in PubMed, CAS, Scopus and Google Scholar

- Research which is freely available for redistribution 